\title{
Influence of continuous exposure to gaseous ozone on the quality of red bell
}

\section{peppers, cucumbers and zucchini}

\author{
Marcin Glowacz*, Richard Colgan, Deborah Rees \\ Natural Resources Institute, University of Greenwich, Chatham, ME4 4TB, United Kingdom \\ *Corresponding author. Tel.: +44 (0) 1634883564 \\ E-mail address: $\underline{\text { M.M.Glowacz@greenwich.ac.uk }}$ \\ ABSTRACT
}

The effect of continuous exposure to ozone on quality changes during the storage of red bell peppers, cucumbers and zucchini was investigated. Peppers were stored at $14{ }^{\circ} \mathrm{C}$ and were exposed to ozone at 0.1 and $0.3 \mu \mathrm{mol} \mathrm{mol}^{-1}$, while cucumbers and zucchini were stored at 12 and $8{ }^{\circ} \mathrm{C}$, respectively and exposed to ozone at $0.1 \mu \mathrm{mol} \mathrm{mol}{ }^{-1}$. The content of fructose $(2.75 \mathrm{~g} / 100 \mathrm{~g} \mathrm{FW})$ and glucose $(2.00 \mathrm{~g} / 100 \mathrm{~g} \mathrm{FW})$ in red bell peppers exposed to ozone at $0.1 \mu \mathrm{mol} \mathrm{mol}^{-1}$ was increased by 8 and $7 \%$, respectively when compared to controls. Continuous exposure to ozone at $0.3 \mu \mathrm{mol} \mathrm{mol}^{-1}$, on the other hand, had no effect on fructose (2.52 g/100 g FW) and glucose (1.88 g/100 g FW) content. The content of vitamin C was significantly enhanced in red bell peppers exposed to ozone at 0.1 and $0.3 \mu \mathrm{mol} \mathrm{mol}^{-1}$ after 7 days of storage, however, this effect was not maintained. After 14 days, vitamin $\mathrm{C}$ content in peppers exposed to ozone at $0.1 \mu \mathrm{mol} \mathrm{mol}{ }^{-1}$ was not significantly different from the control, whereas it was reduced at $0.3 \mu \mathrm{mol} \mathrm{mol}{ }^{-1}$. Total phenolics content was increased in peppers exposed to ozone at $0.1 \mu \mathrm{mol} \mathrm{mol}^{-1}$, but was unaffected at $0.3 \mu \mathrm{mol} \mathrm{mol}{ }^{-1}$. Continuous exposure of red bell peppers to ozone at 0.1 and $0.3 \mu \mathrm{mol} \mathrm{mol}{ }^{-1}$ had no significant effect on weight loss, texture and colour. In cucumbers and zucchini, continuous exposure to ozone at $0.1 \mu \mathrm{mol} \mathrm{mol}^{-1}$ reduced weight loss by more than $40 \%$ and improved texture maintenance, while having no significant effect on their biochemistry. The findings from this study suggest that continuous exposure to ozone at $0.1 \mu \mathrm{mol} \mathrm{mol}{ }^{-1}$ is a promising method for shelf-life extension of cucumbers and zucchini. Even though in red bell peppers continuously exposed to ozone at $0.1 \mu \mathrm{mol} \mathrm{mol}{ }^{-1}$ sugars and phenolics content was increased, further work is still needed to better understand the exact mechanism of ozone action and its potential for the industrial use.

Keywords:

Fresh produce

Quality evaluation

Storage

\section{Introduction}

The economic value of trade in fresh produce is constantly growing, due to increasing consumer demand. Consumers care more and more about what they eat and fresh produce has been recognised as a healthy food, for example being rich in antioxidants (Llorach et al., 2008; Alothman et al., 2010; Yeoh et al., 2014). The shelf-life of fresh produce, however, is shorter than other food products, and is determined by initial quality at 
harvest (Clarkson et al., 2003; Zhang et al., 2007) and subsequent storage conditions (Nunes et al., 2009). New techniques for reducing undesired microbial contamination, spoilage and decay, as well as maintaining the product's visual, textural and nutritional quality are required at all steps of the production and distribution chain.

Treatment with ozone $\left(\mathrm{O}_{3}\right)$ is currently being explored as a practical method to reduce/eliminate microorganisms present in food (Khadre et al., 2001; Guzel-Seydim et al., 2004). Ozone is a well-known strong oxidizing agent that has been used by the fresh produce industry as an antimicrobial agent for a number of years and has been generally recognised as safe (GRAS). The use of ozone by the fresh produce industry is a good alternative to chemical treatments, such as the use of chlorine as it leaves no chemical residues. Recently, there has been an increasing interest in the use of ozone as a postharvest treatment of fruit and vegetables (Horvitz and Cantalejo, 2014). Only those treatments that reduce microbial contamination and extend the shelf-life of the product without having an adverse effect on the product's visual, textural and nutritional quality (Allende et al., 2008) can be recommended and subsequently incorporated into the supply chain.

A number of studies (Ketteringham et al., 2006; Alexandre et al., 2011; Horvitz and Cantalejo, 2012 Alexopoulos et al., 2013) investigated the efficiency of ozone in reducing microbial counts on peppers, however, only one study (Horvitz and Cantalejo, 2012) as sessed physicochemical properties of the produce. Microbial contamination of peppers can be reduced by applying ozone in either gaseous (Horvitz and Cantalejo, 2012) or aqueous (Alexandre et al., 2011; Alexopoulos et al., 2013) form. Ketteringham et al. (2006), however, did not observe reductions in microbial counts in fresh-cut peppers washed with ozonated water at 0.30-0.35, 0.38-0.45 and 3.85-3.95 $\mu \mathrm{mol} \mathrm{mol}{ }^{-1}$ for $20 \mathrm{~s}$ to $30 \mathrm{~min}$, and suggested that this could be due to cut surfaces that promoted leaching of organic matter, thus providing a higher concentration of organic matter to react with ozone, thereby reducing the concentration of ozone available to act as an antimicrobial agent. Thus, Ketteringham et al. (2006) suggested treating whole rather than pre-cut peppers. Interestingly, ozonated water at $1 \mu \mathrm{mol} \mathrm{mol} \mathrm{l}^{-1}$ applied for 3-5 min, has recently been found to be efficient in reducing mesophilic and psychrotrophic bacteria, yeast and mould counts on fresh-cut peppers (Horvitz and Cantalejo, 2012). Furthermore, Horvitz and Cantalejo (2012) reported that gas eous ozone at $0.7 \mu \mathrm{mol} \mathrm{mol} \mathrm{m}^{-1}$ applied for 1-5 min prior to storage was even more efficient as a sanitizer when compared with aqueous form at $1 \mu \mathrm{mol} \mathrm{mol}{ }^{-1}$ applied for the same time. These findings highlight the need to focus on the effects of gaseous ozone on the quality of red bell peppers. Fruit and vegetables can be treated either with high ozone concentration prior to storage (Yeoh et al., 2014) or they might be continuously/intermittently exposed to lower ozone concentration 
during storage (Aguayo et al., 2006; Tzortzakis et al., 2007b). There are no reports on continuous exposure of red bell peppers to low concentrations of ozone.

On the other hand, the availability of information regarding the effects of ozone exposure on the quality of cucumbers is limited (Skog and Chu, 2001), while to our knowledge, there has not been any research dealing with effects of ozone exposure on zucchini.

Exposure of fresh produce to ozone is expected to induce production of reactive oxygen species (ROS) (Kangasjarvi et al., 2005); too much stress, however, leads to cell death, evidenced by discolouration and loss of texture. Thus, the dose of ozone has to be appropriately adjusted for each commodity (Forney et al., 2003). For safety reasons, within the fresh produce industry, it is important to keep the levels of ozone low; the recommended limit set for humans by the US Occupational Health and Safety Administration is $0.1 \mu \mathrm{mol} \mathrm{mol}^{-1}$ averaged over an 8 hour shift. Ozone can also cause damage to equipment by, for example causing cracks in rubber. Thus, the aim of this study was to determine the effect of continuous exposure to low concentrations of ozone (0.1-0.3 $\left.\mu \mathrm{mol} \mathrm{mol} \mathrm{m}^{-1}\right)$ on quality changes during the storage of red bell peppers, cucumbers and zucchini.

\section{Materials and methods}

\subsection{Plant material and handling}

Red bell peppers (Capsicum annuumL.) variety Ferrari (commercially mature but not fully ripe; 75-85 $\mathrm{mm}$ in diameter) and mature cucumbers (Cucumis sativus L.) variety High Jack ( 30 cm long) were supplied by a commercial greenhouse and pack-house facility, Thanet Earth, Kent, UK, whereas zucchini (Cucurbita pepo L.) variety Prometheus (small; 12-16 cm long) were supplied by Mack Multiples Ltd, Kent, UK. On arrival, all fruit were graded to be free from visible defects.

For experiment 1 , that addressed the effect of ozone exposure on quality changes during the storage of red bell peppers, fruit were placed for $14 \mathrm{~d}$ in six ( 2 containers per treatment) $30 \mathrm{~L}$ sealable plastic containers (24 fruit per treatment) supplied with humidified air (RH, 92 $\pm 2 \%$ ) at constant air flow of $0.05 \mathrm{~m}^{3} \mathrm{~h}^{-1}$ as a continuous, flow-through systemat $14 \pm 1{ }^{\circ} \mathrm{C}$, as recorded using temperature and humidity loggers (Lascar Electronics Ltd, UK). Ozone was supplied at approximately $0.1 \pm 0.015$ and $0.3 \pm 0.030 \mu \mathrm{mol} \mathrm{mol}^{-1}$, using ozone generators (Onnic International, UK) placed within the containers close to air inlet. Air was circulated inside the box to ensure even distribution of ozone. Ozone concentration was monitored periodically, on the sampling day before taking the produce out from containers for subsequent assessment, with an L-106 Ozone Monitor (2B Technologies, US). Produce quality (weight loss, texture, colour, sugars, soluble solids and pH, ascorbic acid and total phenolics) was assessed on arrival and after 7 and $14 \mathrm{~d}$ of storage, respectively. 
For experiment 2, that addressed the effect of ozone exposure on quality changes during the storage of cucumbers and zucchini, fruit were placed for $17 \mathrm{~d}$ in sixteen ( 4 containers per treatment) $30 \mathrm{~L}$ sealable plastic containers (48 fruit per treatment) supplied with humidified air ( $\mathrm{RH}, 90 \pm 2 \%$ ) at a constant air flow of $0.05 \mathrm{~m}^{3} \mathrm{~h}^{-1}$ as a continuous, flow-through systemat $12 \pm 1{ }^{\circ} \mathrm{C}$ (cucumbers) and $8 \pm 1{ }^{\circ} \mathrm{C}$ (zucchini), respectively. Ozone at $0.3 \pm 0.030 \mu \mathrm{mol} \mathrm{mol}{ }^{-1}$ was found injurious to the fruit, thus in experiment 2 only the lower dose at approximately $0.1 \pm 0.015 \mu \mathrm{mol} \mathrm{mol}{ }^{-1}$ was used.Produce quality (weight loss, texture, colour, ascorbic acid and total phenolics), however, was assessed more frequently, i.e. on arrival and after 6, 10, 13 and $17 \mathrm{~d}$ of storage, respectively.

Storage conditions for both experiments were advised by fruit suppliers to simulate the conditions that produce is facing at their facilities, so that the findings from this research could have a practical value for them.

\subsection{Measurements}

\subsubsection{Weight loss}

All fruit were labelled and weighed on arrival (day 0). Weight loss (\%) was determined by comparing the weight of each fruit on the sampling day with their initial weight determined on day 0 .

\subsubsection{Texture analysis}

Firmness of red bell peppers was determined following the method of Vega-Galvez et al. (2009) with some modifications. Fruit firmness was determined (4 measurements per fruit) using a TA.XT plus Texture Analyser(Stable Micro Systems, UK) equipped with a 2-mm diameter probe (puncture test) and a $0.05 \mathrm{kN}$ load cell. The probe was driven $5.0 \mathrm{~mm}$ at a speed of $1.7 \mathrm{~mm} \mathrm{~s}^{-1}$ and the maximu $\mathrm{m}$ force $(\mathrm{N})$ was recorded.

Firmness of cucumbers and zucchini was determined following the method of Hurr et al. (2013) with some modifications. Fruit firmness was determined (5 measurements per fruit) using a TA.XT plus Texture Analyser(Stable Micro Systems, UK) equipped with a convex-tip probe; 8-mm diameter for whole fruit firmness and 2-mm diameter for mesocarp firmness, and a $0.05 \mathrm{kN}$ load cell. The probe was driven $2.5 \mathrm{~mm}$ at a speed of $0.83 \mathrm{~mm} \mathrm{~s}^{-1}$ and the maximu $\mathrm{m}$ force $(\mathrm{N})$ was recorded.

\subsubsection{Colour}

Skin colour measurements were taken using a Minolta CR-400 chroma meter (Minolta, Japan) with an $8 \mathrm{~mm}$ diameter measuring head and a C illuminant calibrated with manufacturer's standard white plate. Colour changes were quantified for 12 fruit from each sample ( 5 measurements per pepper, 3 measurements per cucumber and zucchini) in the $L^{*}, a^{*}$ and $b^{*}$ colour space (Abbott, 1999). Hue angle $\left(H^{\circ}\right)$ was then calculated as $H^{\circ}=\tan ^{-1}\left(b^{*} / a^{*}\right)$, when $a^{*}$ and $b^{*}$ were $>0$ and $H^{\circ}=180+\tan ^{-1}\left(b^{*} / a^{*}\right)$, when $a^{*}$ was $<0$ and $b^{*}$ was $>0$. 


\subsubsection{Soluble solids and $p H$}

Soluble solids content (SSC) was measured using an eclipse handheld refractometer (Bellingham \& Stanley Ltd, UK) and expressed in ${ }^{\circ}$ Brix. The $\mathrm{pH}$ was measured using a Jenway $3510 \mathrm{pH}$ meter (Bibby Scientific Ltd, UK).

\subsubsection{Sugar analyses}

Freeze-dried pepper samples were ground into powder using a mortar and pestle. Extracts for sugars determination were prepared as described elsewhere (Gine Bordonaba and Terry, 2010) with some modifications. Briefly, aliquots of $50 \mathrm{mg}$ were extracted with $1 \mathrm{ml}$ of ethanol (Fisher Scientific Ltd, UK) for $2 \mathrm{~h}$ in a shaking water bath at $70{ }^{\circ} \mathrm{C}$. Samples were centrifuged at $10,000 \mathrm{x}$ g for 4 minutes and then filtered through $0.45 \mu \mathrm{l}$ syringe filters (Chromacol Ltd, UK). The volume of $10 \mu \mathrm{l}$ was injected into an Agilent 1200 series HPLC (Agilent, UK) with a Zorbax Carbohydrate Analysis column (150 mm x $4.6 \mathrm{~mm}$ x $5 \mu \mathrm{m})$ (Agilent, UK) and Zorbax NH2 guard column (Agilent, UK) at a flow rate of $1.0 \mathrm{ml} \mathrm{min}^{-1}$. The mobile phase consisted of $75 \%$ of acetonitrile (Fisher Scientific Ltd, UK) and 25\% water. The concentration of fructose, glucose and sucrose was determined according to external fructose, glucose and sucrose standards (Sigma-Aldrich, UK).

\subsubsection{Total ascorbic acid extraction and determination}

Ascorbic acid (AsA) was extracted and analysed using a method described by Bergquist et al. (2006) with some modifications. Samples were extracted with cold $\left(4{ }^{\circ} \mathrm{C}\right) 3.0 \%\left(30 \mathrm{~g} / \mathrm{l}\right.$ w/v in $\left.\mathrm{H}_{2} \mathrm{O}\right)$ meta-phosphoric acid $\left(\mathrm{HPO}_{3}\right)$ (Sigma-Aldrich, UK). Samples were homogenized with a Janke \& Kunkel IKA Labortechnik ultraturrax T25 homogenizer (IKA, Germany). The extracts were centrifuged at $4,000 \mathrm{x}$ g for $40 \min$ at $4{ }^{\circ} \mathrm{C}$. Supernatants were filtered through $0.45 \mu \mathrm{l}$ syringe filters (Chromacol Ltd, UK) and $1.0 \mathrm{ml}$ was collected in Eppendorf tubes. Following filtration, extracts were microfuged at 9,300 x g for 5 min. Finally, $500 \mu$ was transferred into HPLC vials for As A determination. Another $500 \mu \mathrm{l}$ was transferred into new $1.5 \mathrm{ml}$ Eppendorf tubes and mixed thoroughly, with an equal volume of $1 \%\left(11 \mathrm{mg} / \mathrm{ml} \mathrm{w/v} \mathrm{in} 1 \mathrm{M} \mathrm{K}_{2} \mathrm{HPO}_{4} / \mathrm{H}_{2} \mathrm{O}(1 / 4\right.$, v/v)) DTT solution (DL-Dithiothreitol) (Sigma-Aldrich, UK). These samples were left for $40 \mathrm{~min}$ at room temperature $\left(20 \pm 1.0^{\circ} \mathrm{C}\right)$, and then microfuged at $9,300 \mathrm{xg}$ for $5 \mathrm{~min}$. Samples were transferred into HPLC vials for total As A (As A + DHA) determination. Samples were analysed using an Agilent 1100 HPLC (Agilent, UK) with a Luna $5 \mu \mathrm{m} \mathrm{NH} 2100$ A column $(250 \mathrm{~mm} \times 4.6 \mathrm{~mm})$ (Phenomenex, UK) at a flow rate of $1.2 \mathrm{ml} \mathrm{min}^{-1}$. The mobile phase consisted of $25 \% 15 \mathrm{mmol} \mathrm{l}^{-1}\left(1.725 \mathrm{~g} / \mathrm{l} / \mathrm{v}\right.$ in $\left.\mathrm{H}_{2} \mathrm{O}\right)$ of $\mathrm{NH}_{4} \mathrm{H}_{2} \mathrm{PO}_{4}$ (mono ammonium phosphate) (Sigma-Aldrich, UK) and 75\% of acetonitrile (Fisher Scientific Ltd, UK); pH was adjusted to 3.9 with $1 \mathrm{M}$ ortho-phosphoric acid $\left(\mathrm{H}_{3} \mathrm{PO}_{4}\right)$ (Acros Organics, UK). The concentration of As A and DHA was determined 
according to external As A standards (Sigma-Aldrich, UK) of 10, 25, 50 and $100 \mu \mathrm{mol} \mathrm{mol}{ }^{-1}$. The volume of 20 $\mu \mathrm{l}$ of each sample was analysed in this process.

\subsubsection{Total phenolics determination}

Total phenolic content (TPC) of the fruit extracts was determined as gallic acid equivalent (GAE) using the Folin-Ciocalteu assay, which was described by Singleton and Rossi (1965). Each sample was extracted with $80 \%$ methanol (Fisher Scientific Ltd, UK). A $20 \mu \mathrm{l}$ aliquot of extract was diluted with $1.58 \mathrm{ml}$ deionised water, and then was mixed with $100 \mu \mathrm{l}$ of Folin \& Ciocalteu's phenol reagent (Sigma-Aldrich, UK). After standing for $4 \mathrm{~min}$ at room temperature, $300 \mu \mathrm{l}$ of the sodium carbonate (Sigma-Aldrich, UK) solution (200 g/L w/v) was added. The solutions were mixed and allowed to stand for $2 \mathrm{~h}$ in the dark at room temperature $\left(20.0 \pm 1.0{ }^{\circ} \mathrm{C}\right)$. Next, the absorbance was measured at $765 \mathrm{~nm}$ using a CE 9200 double beam UV/VIS spectrophotometer (CECIL Instruments Limited, UK). A calibration curve was prepared using a standard solution of gallic acid (Sigma-Aldrich, UK) of 50, 100, 150, 250, and $500 \mathrm{mg} / \mathrm{L}$.

\subsubsection{Disease incidence}

On the sampling days, red bell peppers, cucumbers and zucchini were assessed for signs of rotting, by giving them a score (0 or $1-$ no/ signs of rotting, respectively). Disease incidence (DI) was expressed as the proportion $(\%)$ of fruit showing signs of rotting out of the total number of fruit in each treatment.

\subsubsection{Ethylene concentration}

Air samples ( 0.5 l) from the containers with fresh produce were taken in duplicates for each container using SKC Quality Sample Bags and SKC Vac-U-Chamber (SKC Ltd., UK). Ethylene concentration was determined by injecting a $1 \mathrm{ml}$ sample of headspace into a gas chromatograph (ATI-Unicam 610 series) fitted with a flame ionization detector(FID) set at $250{ }^{\circ} \mathrm{C}$ and a $1 \mathrm{~m}$ long, $6 \mathrm{~mm}$ OD glas s column packed with $100 / 120$ mesh.

\subsection{Statistical analysis}

Data are presented as mean values from a fully randomised design. The significance of main effect was established using ANOVA. Tukey's test was used to compare individual treatment values. All statistical analyses were performed using GenStat $11^{\text {th }}$ Edition (Payne et al., 2008) software (VSN International Ltd, UK).

\section{Results and discussion}

\subsection{Weight loss}

As expected, red bell peppers lost weight progressively over the storage period; after $7 \mathrm{~d}$ of storage at $14{ }^{\circ} \mathrm{C}$, weight loss on average was in the range of $1-2 \%(1.4,1.0$ and $1.6 \%$ in control and peppers exposed to 
ozone at 0.1 and $0.3 \mu \mathrm{mol} \mathrm{mol} \mathrm{m}^{-1}$, respectively) and increased to 3-4\% (3.8, 3.6 and 3.5\% in control and peppers exposed to ozone at 0.1 and $0.3 \mu \mathrm{mol} \mathrm{mol}{ }^{-1}$, respectively) after $14 \mathrm{~d}$, respectively. No significant difference, however, was found between control peppers and those exposed to ozone at 0.1 and $0.3 \mu \mathrm{mol} \mathrm{mol}{ }^{-1}$. These findings are in agreement with others, who observed that in peppers exposed to relatively low concentration of ozone weight loss was unaffected (Horvitz and Cantalejo, 2012) with similar response being observed in tomatoes (Tzortzakis et al., 2007a).

On the other hand, a significantly $(P<0.05)$ higher weight loss, was observed in air-stored (control) cucumbers when compared with their ozone-exposed $\left(0.1 \mu \mathrm{mol} \mathrm{mol} \mathrm{l}^{-1}\right)$ counterparts. This difference was already apparent after $6 \mathrm{~d}$ of storage at $12{ }^{\circ} \mathrm{C}$, when weight loss in control cucumbers reached $3.3 \%$, whereas it was only $1.5 \%$ in their ozone-exposed counterparts. At the end of the storage period, weight loss in ozone-exposed cucumbers did not exceed $3.0 \%$, while the control samples lost nearly $6.0 \%$ of their weight, indicating that ozone exposure prevented water loss from the fruit. Similar results were observed in zucchini, where at the end of the storage period, in ozone-exposed samples weight loss did not exceed 5.0\%, whereas in control samples, with visible signs of shrivelling, it reached $12.0 \%$. These findings are notable, since in the majority of studies (Forney et al., 2003; Horvitz and Cantalejo, 2012) ozone exposure had no effect on weight loss of produce. However, in a recent study of Ali et al. (2014), exposure to ozone at 1.5 to $5 \mu \mathrm{mol} \mathrm{mol} \mathrm{m}^{-1}$ for $96 \mathrm{~h}$ resulted in reduced weight loss of papaya fruit. These authors suggested that this positive response might be related to the thick cuticle of the papaya fruit which prevented the damage of epidermal tissues by ozone action. Kechinsky et al. (2012) studied the effects of ozone on the epidermis of the papaya fruit with a use of scanning electron microscope images. They reported that ozone treatment at $4 \mu \mathrm{mol} \mathrm{mol} \mathrm{m}^{-1}$ for 1 and 2 min did not affect the fruit surface. The mechanism of ozone action may involve its effect on stomata, which have previously been found to be closed in response to ozone in cucumber (Agrawal et al., 1993) and spinach (Calatayud et al., 2004) leaves. The amount of water los s by a fruit during storage, however, may also vary due to cuticle thickness, and this probably explains the higher weight loss observed in zucchini when compared with cucumbers.

Interestingly, Skog and Chu (2001) did not observe any effect on weight loss when cucumbers were exposed to ozone at $0.04 \mu \mathrm{mol} \mathrm{mol}{ }^{-1}$ during storage for $12 \mathrm{~d}$ at $10{ }^{\circ} \mathrm{C}$. This different response might be due to different dose of ozone being used in their study or the fact that they stored cucumbers in the presence of ethylene at 1.5-2.0 $\mu \mathrm{mol} \mathrm{mol}^{-1}$. Exposure to ethylene has been reported to reduce the quality of cucumbers (Hurr et al., 2013) leading to softening of the fruit. 


\subsection{Texture}

Texture loss during storage is a serious problem because it reduces marketability of the product. Red bell peppers are highly perishable and are not suitable for long term storage. Thus, it is not surprising that texture loss from $8.85 \mathrm{~N}$ to $6.96,7.30$ and $6.86 \mathrm{~N}$ in control and peppers exposed to 0.1 and $0.3 \mu \mathrm{mol} \mathrm{mol}^{-1}$ ozone respectively was observed after $14 \mathrm{~d}$ of storage at $14{ }^{\circ} \mathrm{C}$. Texture loss was partly associated with the water loss. The lowest texture was observed in peppers exposed to ozone at $0.3 \mu \mathrm{mol} \mathrm{mol}^{-1}$ which were slightly but not significantly softer when compared with other samples. In agreement with the study of Horvitz and Cantalejo (2012), ozone exposure at 0.1 and $0.3 \mu \mathrm{mol} \mathrm{mol}^{-1}$ had no significant effect on texture maintenance in red bell peppers.

The firmness of both cucumbers and zucchini (Fig. 1), on the other hand, was found to be significantly $(P<0.05)$ better maintained in fruit samples exposed to ozone at $0.1 \mu$ mol mol $^{-1}$; the effect being more pronounced in zucchini (Fig. 1B), probably due to higher water loss of zucchini control samples. Mesocarp firmness was not affected by the treatment. These results are not surprising, as several studies have already reported better firmness retention in ozone exposed fruit, e.g. in cucumbers continuously exposed to ozone at $0.04 \mu \mathrm{mol} \mathrm{mol}^{-1}$ (Skog and Chu, 2001), in papaya exposed to ozone at 1.5-3.5 $\mu \mathrm{mol} \mathrm{mol}^{-1}$ for $96 \mathrm{~h}$ (Ali et al., 2014) and tomatoes (Aguayo et al., 2006; Tzortzakis et al., 2007a; Rodoni et al., 2010), where softening of the fruit, associated with ripening, was delayed in ozone-exposed samples. Rodoni et al. (2010) conducted analyses of the cell walls, and found a decreased activity of pectin methylesterase (PME) in ozone-exposed tomato fruit. These authors suggested that delayed fruit softening was related to reduced solubilisation and depolymerisation of pectin polysaccharides. 


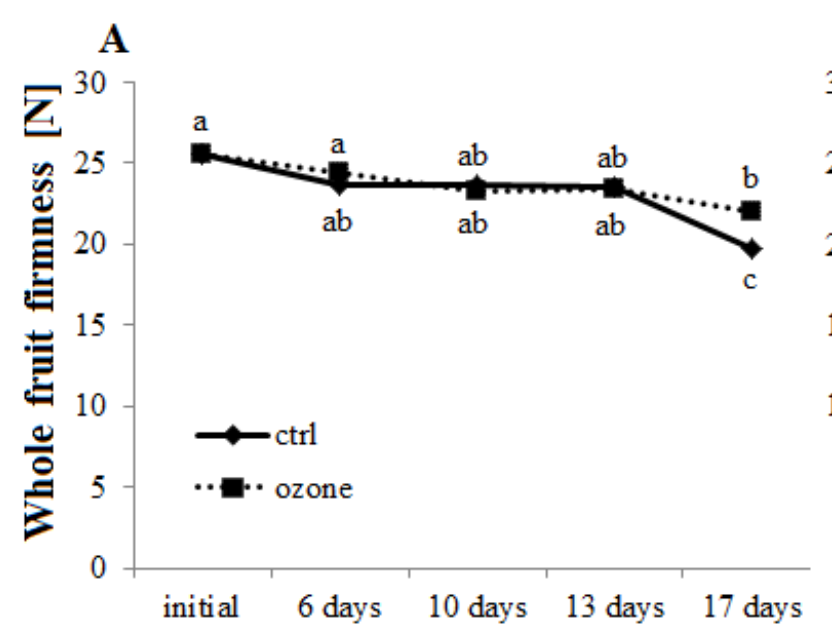

Time of storage [days]
B

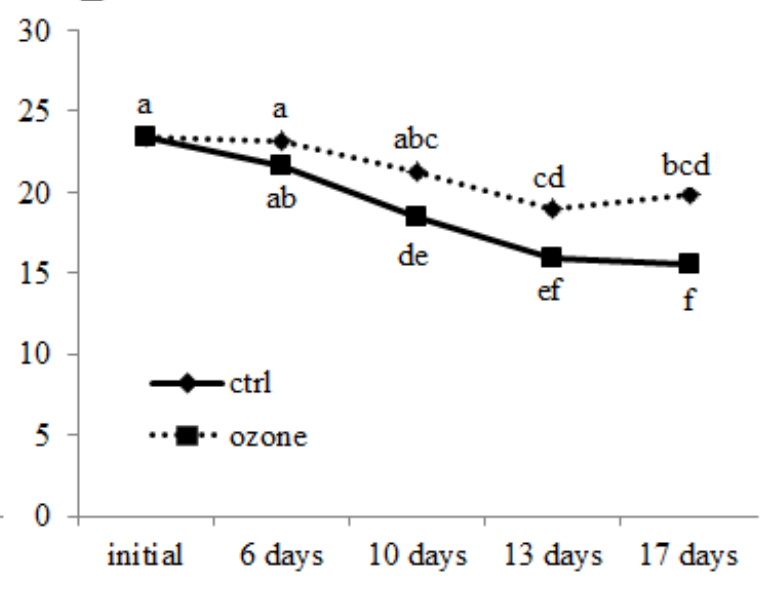

Time of storage [days]

Fig. 1. Effect of continuous exposure to ozone at $100 \mu \mathrm{mol} \mathrm{mol}{ }^{-1}$ on firmness $[\mathrm{N}]$ maintenance during the storage of cucumbers (A) and zucchini (B) for $17 \mathrm{~d}$ at 12 and $8{ }^{\circ} \mathrm{C}$, respectively. Data represent mean values from 12 replicates. Different letters indicate that values are significantly different $(P<0.05)$.

It is apparent from this study that in those commodities, where exposure to ozone can significantly reduce water loss during storage, texture maintenance would be improved. Ozone dose (ozone concentration $\mathrm{x}$ time of exposure), however, has to be properly adjusted, so that it is not injurious to the produce.

\subsection{Colour}

The colour of the epidermis of the red bell peppers at harvest was orange/red and corresponded to a hue angle $\left(H^{\circ}\right)$ of 40.03 . This value, together with $b^{*}$ value declined during $14 \mathrm{~d}$ of storage at $14{ }^{\circ} \mathrm{C}$, indicating that the skin colour changed to dark red. No difference in $H^{\circ}, L^{*}, a^{*}$ and $b^{*}$ values, however, was observed between control and ozone-treated samples throughout the storage period (Table 1). These findings are similar to those reported by Horvitz and Cantalejo (2012), who reported that ozone treatment at $0.7 \mu \mathrm{mol} \mathrm{mol}^{-1}$ for up to $5 \mathrm{~min}$ had no effect on colour of minimally processed peppers. This finding suggest that continuous exposure to low doses of ozone, i.e. $0.1-0.3 \mu \mathrm{mol} \mathrm{mol}{ }^{-1}$, would neither bleach the pigments nor be injurious to the produce. 


\section{Table 1}

Effect of ozone exposure at 0.1 and $0.3 \mu \mathrm{mol} \mathrm{mol}{ }^{-1}$ on colour characteristics during the storage of peppers for 14 d at $14{ }^{\circ} \mathrm{C}$. Data represent mean values from 12 replicates. Different letters indicate that values are significantly different $(P<0.05)$.

\begin{tabular}{|c|c|c|c|c|c|}
\hline Time of storage & Treatment & $L^{*}$ (lightness) & $a *($ redness $)$ & $b^{*}($ yellowness $)$ & $H^{\circ}$ (hue angle) \\
\hline \multirow[t]{2}{*}{ Initial } & & $37.71 \mathrm{a}$ & $26.14 \mathrm{c}$ & $22.06 \mathrm{a}$ & $40.03 \mathrm{a}$ \\
\hline & ctrl & $33.05 \mathrm{c}$ & $29.17 \mathrm{a}$ & $21.30 \mathrm{a}$ & $36.13 \mathrm{~b}$ \\
\hline \multirow[t]{3}{*}{ Day 7} & $0.1 \mu \mathrm{mol} \mathrm{mol}-1$ & $33.22 \mathrm{bc}$ & $28.65 \mathrm{ab}$ & $20.87 \mathrm{a}$ & $35.37 \mathrm{~b}$ \\
\hline & $0.3 \mu \mathrm{mol} \mathrm{mol}{ }^{-1}$ & $33.60 \mathrm{bc}$ & $29.32 \mathrm{a}$ & $21.72 \mathrm{a}$ & $36.50 \mathrm{~b}$ \\
\hline & ctrl & $34.26 \mathrm{bc}$ & $27.14 \mathrm{bc}$ & $17.13 \mathrm{~b}$ & $32.21 \mathrm{c}$ \\
\hline \multirow[t]{2}{*}{ Day 14} & $0.1 \mu \mathrm{mol} \mathrm{mol}{ }^{-1}$ & $33.76 \mathrm{bc}$ & $27.50 \mathrm{bc}$ & $17.43 \mathrm{~b}$ & $32.21 \mathrm{c}$ \\
\hline & $0.3 \mu \mathrm{mol} \mathrm{mol}-1$ & $34.37 \mathrm{~b}$ & $27.25 \mathrm{bc}$ & $17.74 \mathrm{~b}$ & $33.02 \mathrm{c}$ \\
\hline
\end{tabular}

The colour of the fruit epidermis at harvest was dark green and corresponded to a hue angle $\left(H^{\circ}\right)$ of 125.93 and 128.00 in cucumbers and zucchini, respectively. This value declined significantly in cucumbers during $17 \mathrm{~d}$ of storage at $12{ }^{\circ} \mathrm{C}$ due to increase in skin yellowness ( $b^{*}$ value) indicating that skin colour changed from dark to light green. In zucchini, on the otherhand, no significant difference in hue angle was found over the storage period, suggesting that colour changes were less pronounced or more difficult to detect in this commodity, probably due to non-uniform colour of the skin. No difference in $H^{\circ}, L^{*}, a^{*}$ and $b^{*}$ values, however, was observed between control and ozone-treated cucumbers and zucchini samples throughout the storage period (Table 2), with the exception of zucchini after $17 \mathrm{~d}$ of storage at $8{ }^{\circ} \mathrm{C}$, where control fruit became significantly $(P<0.05)$ more yellow. These findings are in agreement with Skog and Chu (2001), who did not observe any colour alteration in ozone exposed cucumbers. The yellowing of control zucchini at the end of storage, on the other hand, may be explained by progressing yellowing and decay, indicating senescence, as sociated with substantial water loss. 
Table 2

Effect of ozone exposure at $0.1 \mu \mathrm{mol} \mathrm{mol} \mathrm{m}^{-1}$ on colour characteristics during the storage of cucumbers and zucchini for $17 \mathrm{~d}$ at 12 and $8{ }^{\circ} \mathrm{C}$, respectively. Data represent mean values from 12 replicates. Different letters (for each commodity) indicate that values are significantly different $(P<0.05)$.

\begin{tabular}{|c|c|c|c|c|c|}
\hline Time of storage & Treatment & $L^{*}$ (lightness) & $a^{*}$ (greenness) & $b^{*}($ yellowness $)$ & $H^{\circ}$ (hue angle) \\
\hline & cucumbers & & & & \\
\hline Initial & & $31.82 \mathrm{e}$ & $-11.11 \mathrm{a}$ & $15.35 \mathrm{e}$ & $125.93 \mathrm{a}$ \\
\hline \multirow{2}{*}{ Day 6} & ctrl & $36.44 \mathrm{~d}$ & $-12.76 a b$ & $18.08 \mathrm{~d}$ & $125.38 \mathrm{a}$ \\
\hline & $0.1 \mu \mathrm{mol} \mathrm{mol}-1$ & $36.08 \mathrm{~d}$ & $-12.12 \mathrm{a}$ & $16.88 \mathrm{de}$ & $126.01 \mathrm{a}$ \\
\hline \multirow{2}{*}{ Day 10} & $\mathrm{ctrl}$ & $36.25 \mathrm{~d}$ & $-12.24 \mathrm{a}$ & $16.99 \mathrm{de}$ & $125.89 \mathrm{a}$ \\
\hline & $0.1 \mu \mathrm{mol} \mathrm{mol}{ }^{-1}$ & $38.18 \mathrm{~cd}$ & $-13.40 \mathrm{abc}$ & $19.10 \mathrm{~cd}$ & $125.22 \mathrm{ab}$ \\
\hline \multirow{2}{*}{ Day 13} & ctrl & $39.77 \mathrm{bc}$ & $-13.98 a b c$ & $21.34 \mathrm{bc}$ & $123.38 \mathrm{c}$ \\
\hline & $0.1 \mu \mathrm{mol} \mathrm{mol}{ }^{-1}$ & $39.41 \mathrm{bc}$ & $-13.91 \mathrm{abc}$ & $21.31 \mathrm{bc}$ & $123.55 \mathrm{bc}$ \\
\hline \multirow{3}{*}{ Day 17} & ctrl & $41.03 \mathrm{ab}$ & $-14.28 b c$ & $23.96 \mathrm{ab}$ & $121.28 \mathrm{~d}$ \\
\hline & $0.1 \mu \mathrm{mol} \mathrm{mol}{ }^{-1}$ & $43.00 \mathrm{a}$ & $-15.03 \mathrm{c}$ & $25.53 \mathrm{a}$ & $120.88 \mathrm{~d}$ \\
\hline & zucchini & & & & \\
\hline Initial & & $27.34 \mathrm{a}$ & -3.75 a & $4.82 \mathrm{~b}$ & $128.00 \mathrm{a}$ \\
\hline \multirow{2}{*}{ Day 6} & ctrl & $28.68 \mathrm{a}$ & $-4.67 \mathrm{a}$ & $6.39 \mathrm{~b}$ & $126.20 \mathrm{a}$ \\
\hline & $0.1 \mu \mathrm{mol} \mathrm{mol}{ }^{-1}$ & $28.48 \mathrm{a}$ & $-4.55 \mathrm{a}$ & $6.27 \mathrm{~b}$ & $126.00 \mathrm{a}$ \\
\hline \multirow{2}{*}{ Day 10} & ctrl & $29.25 \mathrm{a}$ & $-5.28 \mathrm{a}$ & $7.33 \mathrm{ab}$ & $126.30 \mathrm{a}$ \\
\hline & $0.1 \mu \mathrm{mol} \mathrm{mol}-1$ & $27.80 \mathrm{a}$ & $-4.64 \mathrm{a}$ & $6.53 \mathrm{~b}$ & $125.60 \mathrm{a}$ \\
\hline \multirow{2}{*}{ Day 13} & ctrl & $28.64 \mathrm{a}$ & $-4.31 \mathrm{a}$ & $5.95 \mathrm{~b}$ & $126.30 \mathrm{a}$ \\
\hline & $0.1 \mu \mathrm{mol} \mathrm{mol}{ }^{-1}$ & $29.42 \mathrm{a}$ & $-5.18 \mathrm{a}$ & $7.19 \mathrm{ab}$ & $125.50 \mathrm{a}$ \\
\hline \multirow{2}{*}{ Day 17} & $\mathrm{ctrl}$ & $30.93 \mathrm{a}$ & $-6.30 a$ & $9.65 \mathrm{a}$ & $124.30 \mathrm{a}$ \\
\hline & $0.1 \mu \mathrm{mol} \mathrm{mol}-1$ & $28.61 \mathrm{a}$ & $-4.64 \mathrm{a}$ & $6.55 \mathrm{~b}$ & $125.50 \mathrm{a}$ \\
\hline
\end{tabular}

\subsection{Physicochemical properties}

The taste of the product can be affected by a number of factors, including sugarcontent and composition, acidity, organic acids and texture-related mouth feel (Eggink et al., 2012; Piombino et al., 2013). The level of soluble solids is as sociated with sugarcontent and fruit maturity. It generally increases during fruit ripening, and starts to decline when fruit are overripe. The amount of soluble solids increased slightly during the storage of red bell peppers. After $14 \mathrm{~d}$ of storage the lowest level of soluble solids was observed in samples exposed to ozone at $0.1 \mu \mathrm{mol} \mathrm{mol}{ }^{-1}$. Even though, no significant difference was found between the samples, these findings may suggest that there is a potential to slow the ripening of red bell peppers if the dose of ozone is properly adjusted. Fruit ripening has already been found to be delayed in kiwi continuously exposed to ozone

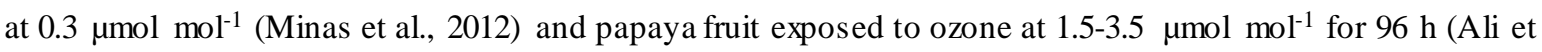
al., 2014) but not when the concentration of ozone was higher, inhibiting the development of full ripe colour and 
resulting in tis sue damage due to its strong oxidizing activity and thus supporting the growth of fungal

pathogens. This underlines the fact that only at certain levels of ozone shelf-life may be extended.

Similar to the study of Horvitz and Cantalejo (2012), ozone exposure had no significant effect on the $\mathrm{pH}$ of pepper juice (Table 3). This is not surprising, since even in those studies that observed some changes in organic acids in produce exposed to ozone (Aguayo et al., 2006; Barboni et al., 2010) the acidity of the product was not affected.

\section{Table 3}

Effect of ozone exposure at 0.1 and $0.3 \mu \mathrm{mol} \mathrm{mol}{ }^{-1}$ on physicochemical properties of red bell peppers during the storage for $14 \mathrm{~d}$ at $14{ }^{\circ} \mathrm{C}$. Data represent mean values from 12 replicates. Different letters indicate that values are significantly different $(P<0.05)$.

\begin{tabular}{|c|c|c|c|c|c|c|}
\hline Time of storage & Treatment & pH & $\begin{array}{l}\text { Soluble solids } \\
\quad\left({ }^{\circ} \text { Brix }\right)\end{array}$ & $\begin{array}{c}\text { Fructose } \\
(\mathrm{g} / 100 \mathrm{~g} \text { FW })\end{array}$ & $\begin{array}{c}\text { Glucose } \\
\text { (g/100 g FW) }\end{array}$ & $\begin{array}{c}\text { Sucrose } \\
(\mathrm{g} / 100 \mathrm{~g} \text { FW })\end{array}$ \\
\hline \multirow{3}{*}{ Day 7} & ctrl & $5.02 \mathrm{a}$ & $5.82 \mathrm{ab}$ & $2.67 \mathrm{ab}$ & $1.97 \mathrm{ab}$ & $0.06 \mathrm{a}$ \\
\hline & $0.1 \mu \mathrm{mol} \mathrm{mol}{ }^{-1}$ & $5.08 \mathrm{a}$ & $5.60 \mathrm{ab}$ & $2.70 \mathrm{ab}$ & $2.07 \mathrm{a}$ & $0.07 \mathrm{a}$ \\
\hline & $0.3 \mu \mathrm{mol} \mathrm{mol}-1$ & $5.06 \mathrm{a}$ & $5.43 \mathrm{~b}$ & $2.60 \mathrm{ab}$ & $1.98 \mathrm{ab}$ & $0.06 \mathrm{a}$ \\
\hline \multirow{3}{*}{ Day 14} & ctrl & $5.03 \mathrm{a}$ & $6.12 \mathrm{a}$ & $2.54 \mathrm{~b}$ & $1.87 \mathrm{~b}$ & $0.06 \mathrm{a}$ \\
\hline & $0.1 \mu \mathrm{mol} \mathrm{mol}{ }^{-1}$ & $5.05 \mathrm{a}$ & $5.85 \mathrm{ab}$ & $2.75 \mathrm{a}$ & $2.00 \mathrm{ab}$ & $0.06 \mathrm{a}$ \\
\hline & $0.3 \mu \mathrm{mol} \mathrm{mol}-1$ & $5.03 \mathrm{a}$ & $5.97 \mathrm{ab}$ & $2.52 \mathrm{~b}$ & $1.88 \mathrm{~b}$ & $0.04 \mathrm{~b}$ \\
\hline
\end{tabular}

Exposure of red bell peppers to ozone at the concentration of $0.1 \mu \mathrm{mol} \mathrm{mol}{ }^{-1}$ led to increased content of fructose and glucose, whereas ozone at $0.3 \mu \mathrm{mol} \mathrm{mol}{ }^{-1}$ had no effect on fructose and glucose but reduced the content of sucrose (Table 3). These results are similar to those of Aguayo et al. (2006), who observed higher fructose and glucose content in tomatoes exposed to ozone applied cyclically at $4 \mu \mathrm{mol} \mathrm{mol}^{-1}$ for 30 min every 3 h. The sugar loss in control samples and those exposed to ozone at $0.3 \mu \mathrm{mol} \mathrm{mol} \mathrm{m}^{-1}$ may be associated with increased respiration. Respiration rate (consumption of $\mathrm{O}_{2}$ and production of $\mathrm{CO}_{2}$ ), which is a measure of physiological activity (Pirovani et al., 1998) increases in response to tis sue damage and as demonstrated in broccoli (Forney et al., 2003), respiration rate increases when the dose of ozone being used is too high which would be due to the damage caused to the produce.

Ozone exposure at $0.1 \mu \mathrm{mol} \mathrm{mol} \mathrm{l}^{-1}$ had no significant effect on As A and DHA content in red bell peppers (Table 4) when compared with control samples, whereas when applied at $0.3 \mu \mathrm{mol} \mathrm{mol}^{-1}$, the As A content after $14 \mathrm{~d}$ of storage at $14{ }^{\circ} \mathrm{C}$ was reduced. Even though vitamin $\mathrm{C}$ content after $7 \mathrm{~d}$ of storage was significantly enhanced in peppers exposed to ozone at 0.1 and $0.3 \mu \mathrm{mol} \mathrm{mol}{ }^{-1}$ (Table 4 ), this effect was not maintained in the end of the storage period due to increase in As A content in control samples. A number of 
authors have found no effect of ozone exposure on As A content in whole tomatoes cyclically exposed to gaseous ozone at $4 \mu \mathrm{mol} \mathrm{mol}{ }^{-1}$ for 30 min every $3 \mathrm{~h}$ (Aguayo ate al., 2006) or continuously exposed to ozone at $1 \mu \mathrm{mol} \mathrm{mol} \mathrm{m}^{-1}$ for $6 \mathrm{~d}$ (Tzortzakis et al., 2007a). Zhang et al. (2005), on the otherhand, observed that in celery washed with ozonated water at 0.03-0.18 $\mu \mathrm{mol} \mathrm{mol} \mathrm{m}^{-1}$ for $5 \mathrm{~min}$, changes in vitamin $\mathrm{C}$ content in response to ozone were dose-dependent. In their study, vitamin C content was significantly increased at all doses of ozone after 3 and $6 \mathrm{~d}$ of storage. Even though, vitamin $\mathrm{C}$ content after $9 \mathrm{~d}$ of storage in celery treated at the highest dose $\left(0.18 \mu \mathrm{mol} \mathrm{mol}{ }^{-1}\right)$ was significantly reduced when compared with their counterparts treated at 0.03 and $0.08 \mu \mathrm{mol} \mathrm{mol} \mathrm{m}^{-1}$, it was not significantly different from control. Changes in AsA content are not surprising as As A is a key antioxidant in plant tissue (Conklin, 2001; Mittler, 2002) and its role is to scavenge ROS that are produced in excess under stress conditions, e.g. high dose of ozone. The findings from this study imply that there is a threshold, where at certain dose of ozone, i.e. high concentration or prolonged exposure, nutritional quality of peppers may be reduced.

\section{Table 4}

Effect of ozone exposure at 0.1 and $0.3 \mu \mathrm{mol} \mathrm{mol} \mathrm{m}^{-1}$ on changes in antioxidant content of red bell peppers during the storage for $14 \mathrm{~d}$ at $14{ }^{\circ} \mathrm{C}$. Data represent mean values from 12 replicates. Different letters indicate that values are significantly different $(P<0.05)$.

\begin{tabular}{|c|c|c|c|c|c|}
\hline Time of storage & Treatment & $\begin{array}{c}\text { AsA } \\
(\mathrm{mg} / 100 \mathrm{~g} \mathrm{FW})\end{array}$ & $\begin{array}{c}\text { DHA } \\
(\mathrm{mg} / 100 \mathrm{~g} \mathrm{FW})\end{array}$ & $\begin{array}{c}\text { vitamin C } \\
(\mathrm{mg} / 100 \mathrm{~g} \text { FW) }\end{array}$ & $\begin{array}{c}\text { Total phenolics } \\
\text { (mg GAE/100 g FW) }\end{array}$ \\
\hline \multirow{3}{*}{ Day 7} & ctrl & $60.9 \mathrm{~b}$ & $4.5 \mathrm{a}$ & $65.4 \mathrm{~b}$ & $79.7 \mathrm{ab}$ \\
\hline & $0.1 \mu \mathrm{mol} \mathrm{mol}-1$ & $67.5 \mathrm{ab}$ & $4.0 \mathrm{a}$ & $71.5 \mathrm{a}$ & 88.4 a \\
\hline & $0.3 \mu \mathrm{mol} \mathrm{mol}{ }^{-1}$ & $66.5 \mathrm{ab}$ & $6.6 \mathrm{a}$ & $73.1 \mathrm{a}$ & $74.3 \mathrm{~b}$ \\
\hline \multirow{3}{*}{ Day 14} & ctrl & 75.8 a & $1.9 \mathrm{a}$ & $77.7 \mathrm{a}$ & $87.8 \mathrm{ab}$ \\
\hline & $0.1 \mu \mathrm{mol} \mathrm{mol}-1$ & $69.8 \mathrm{a}$ & $1.1 \mathrm{a}$ & 70.9 a & $92.3 \mathrm{a}$ \\
\hline & $0.3 \mu \mathrm{mol} \mathrm{mol}{ }^{-1}$ & $64.8 \mathrm{~b}$ & $2.2 \mathrm{a}$ & $67.0 \mathrm{~b}$ & $81.6 \mathrm{ab}$ \\
\hline
\end{tabular}

The content of total phenolics was increased in red bell peppers exposed to ozone at $0.1 \mu \mathrm{mol} \mathrm{mol}^{-1}$ (Table 4), while it was not affected in their counterparts exposed to ozone at $0.3 \mu \mathrm{mol} \mathrm{mol} \mathrm{l}^{-1}$. Total phenolics content has previously been found to be increased in ozone treated banana (Alothman et al., 2010), kiwi (Minas et al., 2012), papaya (Ali et al., 2014) and pineapple (Alothman et al., 2010) when compared with control fruit stored in clean air. Increase in phenolics was also reported (Yeoh et al., 2014) when papaya was treated with gaseous ozone at $9.2 \mu \mathrm{mol} \mathrm{mol}{ }^{-1}$ for 10 or $20 \mathrm{~min}$ prior to storage, but not when the exposure time (30 min) was too long. This may be explained by antioxidant capacity of phenolic compounds, i.e. if the dose of ozone is too high it could result in excess oxidative stress and production of ROS which then need to be scavenged by 
antioxidants, e.g. phenolic compounds. These findings suggest that similarly to changes in As A, the content of phenolic compounds is affected in response to ozone in a dose-dependent manner. The possible mechanism may be associated with increased activity of phenylalanine ammonia lyase (PAL; EC 4.3.1.5) in ozone treated samples or reduced activity of polyphenoloxidase (PPO; EC 1.14.18.1) and/or peroxidase (POD; EC 1.11.1.7), which are all involved in polyphenolbiochemistry (Toivonen and Brummell, 2008).

In the case of cucumbers and zucchini, ozone exposure at $0.1 \mu \mathrm{mol} \mathrm{mol}{ }^{-1}$ had no effect on chemical composition (ascorbic acid and total phenolics) of the fruit (data not presented), which may be related to its limited penetration through the cuticle. No changes in As A and phenolics may also suggest that the level of ozone at $0.1 \mu \mathrm{mol} \mathrm{mol}{ }^{-1}$ is too low to induce production of reactive oxygen species (ROS). On the other hand, since ozone cannot penetrate deeply into the fruit, it could have induced some biochemical/physiological changes in the skin by interacting with cell wall constituents, as has previously been reported (An et al., 2007).

\subsection{Disease incidence}

In trial 1 with red bell peppers, no sign of rotting was observed on the fruit surface during the $14 \mathrm{~d}$ of storage at $14{ }^{\circ} \mathrm{C}$. Once the fruit were cut into halves, the fungal infection was noticed in $4-8 \%$ of the fruit, regardless of the treatment, on the septum and placental region probably due to latent infection present in the fruit at harvest. Since ozone cannot penetrate deeply into the fruit, fungal development could not be prevented. In trial 2 with red bell peppers, no sign of rotting was observed on the fruit surface after $7 \mathrm{~d}$ of storage. After 14 $\mathrm{d}$, however, no sign of rotting was observed only in peppers continuously exposed to ozone at $0.3 \mu \mathrm{mol} \mathrm{mol}^{-1}$. The growth of fungi on stem and peduncle was observed in $8.3 \%$ of the fruit continuously exposed to ozone at $0.1 \mu \mathrm{mol} \mathrm{mol} \mathrm{m}^{-1}$, while in $25 \%$ of the control peppers. In contrast to trial 1 , no fungal infection was noticed inside the fruit used in the trial 2, i.e. the latent infection was not present. The finding from this study suggests that continuous exposure to ozone at doses of 0.1 and $0.3 \mu \mathrm{mol} \mathrm{mol} \mathrm{m}^{-1}$ may efficiently reduce disease incidence in whole red peppers.

In cucumbers, no sign of rotting was observed on the fruit surface after $6 \mathrm{~d}$ of storage at $12{ }^{\circ} \mathrm{C}$. After 10,13 and $17 \mathrm{~d}$ of storage, however, disease incidence was found on 8.3, 16.6, 33.3\% and 8.3, 8.3, and $16.6 \%$ of the control and ozone-exposed fruit, respectively. In zucchini, on the other hand, fungal development was noticed after $10 \mathrm{~d}$ of storage at $8{ }^{\circ} \mathrm{C}$ on $8.3 \%$ of the fruit, regardless the treatment. After 13 and $17 \mathrm{~d}$, signs of rotting were observed on $16.6 \%$ of both control and treated fruit. Fungal development on cucumbers and zucchini was not prevented by continuous exposure to ozone at $0.1 \mu \mathrm{mol} \mathrm{mol}{ }^{-1}$. 
Continuous exposure to ozone at $0.1 \mu \mathrm{mol} \mathrm{mol}{ }^{-1}$ reduced disease incidence in red bell peppers but not in cucumbers and zucchini. This difference may be due to differences in the initial microbial counts, which were not determined in this study or due to several other factors, including skin characteristics of the produce and its sensitivity to ozone, which varies between different commodities.

\subsection{Effect on ethylene}

In the trials with red bell peppers, ethylene concentration within the containers was within the range of 0.005-0.040 $\mu \mathrm{mol} \mathrm{mol} \mathrm{m}^{-1}$ in containers with control samples and those continuously exposed to ozone at $0.1 \mu \mathrm{mol}$ $\mathrm{mol}^{-1}$. The concentration of ethylene was only slightly but not significantly reduced, below $0.010 \mu \mathrm{mol} \mathrm{mol}^{-1}$, in containers with peppers stored with ozone at $0.3 \mu \mathrm{mol} \mathrm{mol}{ }^{-1}$. In the trials with cucumbers and zucchini, the concentrations of ethylene in the containers were even lower, i.e. in the range of $0.002-0.014 \mu \mathrm{mol} \mathrm{mol}^{-1}$ in

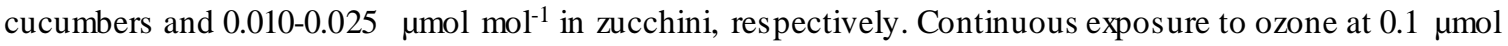
$\mathrm{mol}^{-1}$ had no measureable effect on ethylene concentration within the containers. The lack of effect of ozone on the ethylene concentration could be explained by low ethylene concentrations in all trials (not exceeding 0.040 $\mu \mathrm{mol} \mathrm{mol}^{-1}$ ), thus making it difficult to observe any reduction. The other reason could be that the removal of ethylene at ozone doses of 0.1 and $0.3 \mu \mathrm{mol} \mathrm{mol}^{-1}$ is rather slow. Palou et al. (2001) reported that in an empty $59.78 \mathrm{~m}^{3}$ container after continuous supply of ozone for $24 \mathrm{~h}$, resulting in an ozone concentration of $0.3 \mu \mathrm{mol}$ $\mathrm{mol}^{-1}$, the concentration of ethylene was only reduced by $1 \%$ of its initial value. The efficiency of ozone in ethylene removal, however, was found (Palou et al., 2001) to be significantly increased at higher doses of ozone, i.e. continuous ozone supply at above $1 \mu \mathrm{mol} \mathrm{mol}^{-1}$.

\section{Conclusion}

Continuous exposure to ozone at $0.1 \mu \mathrm{mol} \mathrm{mol} \mathrm{m}^{-1}$ enhanced fructose and glucose, and total phenolics content in red bell peppers. At the same time, it had no significant effect on weight loss, texture and colour. In the case of cucumbers and zucchini, continuous exposure to ozone at $0.1 \mu \mathrm{mol} \mathrm{mol}{ }^{-1}$ reduced weight loss and improved texture maintenance, while having no significant effect on their biochemistry. Ozone cannot penetrate deeply into the fruit, thus it must have induced biochemical/physiological changes in their skin. It is apparent from this work that continuous exposure to ozone at $0.1 \mu \mathrm{mol} \mathrm{mol} \mathrm{m}^{-1}$ had no adverse effect on quality of red peppers, cucumbers and zucchini. The findings from this study suggest that when used at the proper dose, not too high to cause the damage or nutritional quality loss, i.e. continuous exposure to ozone at $0.1 \mu \mathrm{mol}^{\mathrm{mol}}{ }^{-1}$ is a promising method for shelf-life extension of cucumbers and zucchini. Effects of ozone are not considered to be as sociated with removal of ethylene, as ethylene concentrations were lower than $0.04 \mu \mathrm{mol} \mathrm{mol}{ }^{-1}$ in all cases, 
with no significant effect of ozone treatment. Further work, however, is still needed to better understand the exact mechanism of ozone action in case of red peppers and whether its use has the potential for industrial use.

\section{Acknowledgements}

This work was supported by the UK Higher Education Innovation Fund.

\section{References}

Abbott, J.A., 1999. Quality measurement of fruits and vegetables. Postharvest Biol. Technol. 15 (3), 207-225. Agrawal, M., Krizek, D.T., Agrawal, S.B., Kramer, G.F., Lee, E.H., Mirecki, R.M., Rowland, R.A., 1993. Influence of inverse day/night temperature on ozone sensitivity and selected morphological and physiological responses of cucumber. J. Am. Soc. Hortic. Sci. 118 (5), 649-654.

Aguayo,E., Escalona, V.H., Artes, F., 2006. Effect of cyclic exposure to ozone gas on physicochemical, sensorial and microbial quality of whole and sliced tomatoes. Postharvest Biol. Technol. 39 (2), 169-177. Alexandre, E.M.C., Santos-Pedro, D.M., Brandao, T.R.S., Silva, C.L.M., 2011. Influence of aqueous ozone, blanching and combined treatments on microbial load of red bell peppers, strawberries and watercress. J. Food Eng. 105 (2), 277-282.

Alexopoulos, A., Plessas, S., Ceciu, S., Lazar, V., Mantzourani, I., Voidarou, C., Stavropoulou, E., Bezirtzoglou, E., 2013. Evaluation of ozone efficacy on the reduction of microbial population of fresh cut lettuce (Lactuca sativa) and green bell pepper (Capsicum annuum). Food Control 30 (2), 491-496.

Ali, A., Ong, M.K., Forney, C.F., 2014. Effect of ozone pre-conditioning on quality and antioxidant capacity of papaya fruit during ambient storage. Food Chem. 142, 19-26.

Allende, A., Selma, M.V., Lopez-Galvez, F., Villaescusa, R., Gil, M.I., 2008. Role of commercial sanitizers and washing systems on epiphytic microorganisms and sensory quality of fresh-cut escarole and lettuce. Postharvest Biol. Technol. 49 (1), 155-163.

Alothman, M., Kaur, B., Fazilah, A., Bhat, R., Karim, A.A., 2010. Ozone-induced changes of antioxidant capacity of fresh-cut tropical fruits. Innov. Food Sci. Emerg. Technol. 11 (4), 666-671.

An, J., Zhang, M., Lu, Q., 2007. Changes in some quality indexes in fresh-cut green asparagus pretreated with aqueous ozone and subsequent modified atmosphere packaging. J. Food Eng. 78 (1), 340-344.

Barboni, T., Cannac, M., Chiaramonti, N., 2010. Effect of cold storage and ozone treatment on physicochemical parameters, soluble sugars and organic acids in Actinidia deliciosa.Food Chem. 121 (4), 946-951. 
Bergquist, S.A.M., Gertsson, U.E., Olsson, M.E., 2006. Influence of growth stage and postharvest storage on ascorbic acid and carotenoid content and visual quality of baby spinach (Spinacia oleracea L.). J. Sci. Food Agric. 86 (3), 346-355.

Calatayud, A., Iglesias, D.J., Talon, M., Barreno, E., 2004. Response of spinach leaves (Spinacia oleracea L.) to ozone measured by gas exchange, chlorophyll a fluorescence, antioxidant systems, and lipid peroxidation. Photos ynthetica 42 (1), 23-29.

Clarkson, G.J.J., O'Byrne, E.E., Rothwell, S.D., Taylor, G., 2003. Identifying traits to improve postharvest process ability in baby leaf salad. Postharvest Biol. Technol. 30 (3), 287-298.

Conklin, P.L. (2001). Recent advances in the role and biosynthesis of ascorbic acid in plants. Plant Cell Environ. 24 (4), 383-394

Eggink, P.M., Maliepaard, C., Tikunov, Y., Haanstra, J.P.W., Bovy, A.G., Visser, R.G.F., 2012. A taste of sweet pepper: volatile and non-volatile chemical composition of fresh sweet pepper(Capsicum annuum) in relation to sensory evaluation of taste. Food Chem. 132 (1), 301-310.

Forney, C.F., Song, J., Fan, L., Hildebrand, P.D., Jordan, M.A., 2003. Ozone and 1-methylcyclopropene alter the postharvest quality of broccoli. J. Am. Soc. Hortic. Sci. 128 (3), 403-408.

Gine Bordonaba, J., Terry, L.A., 2010. Manipulating the taste-related composition of strawberry fruits $($ Fragaria $\times$ ananassa $)$ from different cultivars using deficit irrigation. Food Chem. 122 (4), 1020-1026.

Guzel-Seydim, Z.B., Greene, A.K., Seydim, A.C., 2004. Use of ozone in the food industry. LWT - Food Sci. Technol. 37 (4), 453-460.

Horvitz, S., Cantalejo, M.J., 2012. Effects of ozone and chlorine postharvest treatments on quality of fresh-cut red bell peppers. Int. J. Food Sci. Technol. 47 (9), 1935-1943.

Horvitz, S., Cantalejo, M.J., 2014. Application of ozone for the postharvest treatment of fruits and vegetables. Crit. Rev. Food Sci. Nutr. 54 (3), 312-339.

Hurr, B.M., Huber, D.J., Vallejos, C.E., Lee, E., Sargent, S.A., 2013. Ethylene-induced overproduction of reactive oxygen species is responsible for the development of watersoaking in immature cucumber fruit. J. Plant Physiol. 170 (1), 56-62.

Kangasjarvi, J., Jaspers, P., Kollist, H., 2005. Signalling and cell death in ozone-exposed plants. Plant Cell Environ. 28 (8), 1021-1036. 
Kechinsky, C.P., Montero, C.R.S., Guimaraes, P.V.R., Norena, C.P.Z., Marc zak, L.D.F., Tessaro, I.C., Bender, R.J., 2012. Effects of ozonized water and heat treatment on the papaya fruit epidermis. Food Bioprod. Process. 90 (2), 118-122.

Ketteringham, L., Gausseres, R., James, S.J., James, C., 2006. Application of aqueous ozone for treating pre-cut green peppers (Capsicum annuum L.). J. Food Eng. 76 (1), 104-111.

Khadre, M.A., Yousef, A.E., Kim, J.G., 2001. Microbiological aspects of ozone applications in food: a review. J. Food Sci. 66 (9), 1242-1252.

Llorach, R., Martinez-Sanchez, A., Tomas-Barberan, F.A., Gil, M.I., Ferreres, F., 2008. Characteris ation of polyphenols and antioxidant properties of five lettuce varieties and escarole. Food Chem. 108 (3), 1028-1038. Minas, I.S., Tanou, G., Belghazi, M., Job, D., Manganaris, G.A., Molassiotis, A., Vasilakakis, M., 2012. Physiological and proteomic approaches to address the active role of ozone in kiwifruit post-harvest ripening. J. Exp. Bot. 63 (7), 2449-2464.

Mittler, R., 2002. Oxidative stress, antioxidants and stress tolerance. Trends Plant Sci. 7 (9), 405-410.

Nunes, M.C.N., Emond, J.P., Rauth, M., Dea, S., Chau, K.V., 2009. Environmental conditions encountered during typical consumer retail display affect fruit and vegetable quality and waste. Postharvest Biol. Technol. 51 (2), 232-241.

Palou, L., Smilanick, J.L., Crisosto, C.H., Mansour, M., 2001. Effect of gaseous ozone exposure on the development of green and blue molds on cold stored citrus fruit. Plant Dis. 85 (6), 632-638.

Payne, R.W., Harding, S.A., Murray, D.A., Soutar, D.M., Baird, D.B., Glaser, A.I., Channing, I.C., 2008. GenStat $11^{\text {th }}$ Edition, Reference Manual.

Piombino, P., Sinesio, F., Moneta, E., Cammareri, M., Genovese, A., Lisanti, M.T., Mogno, M.R., Peparaio, M., Termolino, P., Moio, L., Grandillo, S., 2013. Investigating physicochemical, volatile and sensory parameters playing a positive or a negative role on tomato liking. Food Res. Int. 50 (1), 409-419.

Pirovani, M.E., Piagentini, A.M., Guemes, D.R., Di Pentima, J.H., 1998. Quality of minimally processed lettuce as influenced by packaging and chemical treatment. J. Food Quality 21 (6), 475-484.

Rodoni, L., Casadei, N., Concellon, A., Alicia, A.R.C., Vicente, A.R., 2010. Effect of short-term ozone treatments on tomato (Solanumlycopersicum L.) fruit quality and cell wall degradation. J. Agric. Food Chem. 58 (1), 594-599.

Singleton, V.L., Rossi, J.A., 1965. Colorimetry of total phenolics with phosphomolybdic-phosphotungstic acid reagents. Am. J. Enol. Vitic. 16 (3), 144-158. 
Skog, L.J., Chu, C.L., 2001. Effect of ozone on qualities of fruits and vegetables in cold storage. Can. J. Plant Sci. 81 (4), 773-778.

Toivonen, P.M.A., Brummell, D.A., 2008. Biochemical bases of appearance and texture changes in fresh-cut fruit and vegetables. Postharvest Biol. Technol. 48 (1), 1-14.

Tzortzakis, N., Borland, A., Singleton, I., Barnes, J., 2007a. Impact of atmospheric ozone-enrichment on quality-related attributes of tomato fruit. Postharvest Biol. Technol. 45 (3), 317-325.

Tzortzakis, N., Singleton, I., Barnes, J., 2007b. Deployment of low-level ozone-enrichment for the preservation of chilled fresh produce. Postharvest Biol. Technol. 43 (2), 261-270.

Vega-Galvez, A., Di Scala, K., Rodriguez, K., Lemus-Mondaca, R., Miranda, M., Lopez, J., Perez-Won, M., 2009. Effect of air-drying temperature on physico-chemical properties, antioxidant capacity, colour and total phenolic content of red pepper(Capsicum annuum, L. var. Hungarian). Food Chem. 117 (4), 647-653.

Yeoh, W.K., Ali, A., Forney, C.F., 2014. Effects of ozone on major antioxidants and microbial populations of fresh-cut papaya. Postharvest Biol. Technol. 89, 56-58.

Zhang, L., Lu, Z., Yu, Z., Gao, X., 2005. Preservation of fresh-cut celery by treatment of ozonated water. Food Control 16 (3), 279-283.

Zhang, F.Z., Wagstaff, C., Rae, A.M., Sihota, A.K., Keevil, C.W., Rothwell, S.D., Clarkson, G.J.J., Michelmore, R.W., Truco, M.J., Dixon, M.S., Taylor, G., 2007. QTLs for shelf life in lettuce co-locate with those for leaf biophysical properties but not with those for leaf developmental traits. J. Exp. Bot. 58 (6), 14331449. 